\title{
Effect of River Indus Sand on Concrete Tensile Strength
}

\author{
Muhammad Tahir Lakhiar \\ Faculty of Civil and Environmental \\ Engineering \\ Universiti Tun Hussein Onn \\ Malaysia \\ gf170030@siswa.uthm.edu.my
}

\author{
Anees Ahmed Vighio \\ Department of Civil Engineering, \\ Mehran University of Engineering and \\ Technology \\ Pakistan \\ aneesahmedvighio08@gmail.com
}

\author{
Noridah Mohamad \\ Faculty of Civil and Environmental \\ Engineering \\ Universiti Tun Hussein Onn \\ Malaysia \\ noridah@uthm.edu.my
}

Ashfaque Ahmed Jhatial

Faculty of Civil and Environmental Engineering

Universiti Tun Hussein Onn Malaysia

aajhatial@hotmail.com

\author{
Muhammad Abu Bakar Shaikh \\ Department of Civil Engineering \\ Mehran University of Engineering and \\ Technology \\ Pakistan \\ muhammad.abubakar@faculty.muet.edu.pk
}

\author{
Abdul Aziz Abdul Samad \\ Faculty of Civil and Environmental \\ Engineering \\ Universiti Tun Hussein Onn \\ Malaysia \\ azizs@uthm.edu.my
}

\begin{abstract}
In the development of Pakistan construction industry, the utilization of River Indus sand in concrete as fine aggregate has expanded tremendously. The aim of this research is to study the effect of Indus River sand on the tensile strength of various grades of concrete when it is utilized as fine aggregate. Concrete Samples of M15, M20 and M25 grade concrete were cured for 7, 14, 21 and 28 days. Based on the results, it is found that concrete became less workable when Indus river sand was utilized. It is recorded that tensile strength of concrete is decreased from $5 \%$ up to $20 \%$ in comparison with hill sand. The results were derived from various concrete grades.
\end{abstract}

Keywords-tensile strength; workability; river Indus sand; hill sand

\section{INTRODUCTION}

Concrete is broadly utilized as building material because of it is highly durable, easily accessible and economical [1]. Basically, concrete is a blend of binder, aggregates (coarse and fine), water and admixtures [2-3]. Fine aggregate is an important ingredient in concrete occupying $25 \%$ to $35 \%$ of its volume. It is utilized as filler in concrete. The composition, shape, and size of the fine aggregates have great influence on the fresh and hardened properties of concrete [4-5]. In Indus River there is a siltation problem which causes negative effects on storage capacity, water quality and subsequently, reduces power and irrigation capability [6]. Normally, hill sand is used as fine aggregate in Pakistan construction industry, which makes the concrete un-economical in northern areas of Sindh. To overcome this problem, in this research River Indus sand was used as fine aggregate to make the concrete economical and solve the siltation problem. In the experimental work, hill sand was fully replaced by Indus River sand. The workability and tensile strength of concrete were examined with comparison to the conventional concrete which used hill sand as fine aggregates.

\section{LITERATURE REVIEW}

Authors in [7] analyzed the M25 grade concrete at different curing regimes $(7,14$ and 28 days). Foundry sand replaced natural sand with $10 \%, 20 \%, 30 \%, 40 \%$ and $50 \%$ by weight of fine aggregate. The results indicated that the compressive strength increased up to $30 \%$. However, further increment of replacement percentage showed a decrease in compressive strength. Authors in [8] experimented with the mechanical properties of concrete at different proportions of $0 \%, 15 \%$, $25 \%$ and $35 \%$ where natural sand was replaced by foundry sand. The results concluded that the optimum percentage was $25 \%$ which gave the maximum strength. Authors in [9] studied M25 grade concrete at different curing regimes (7, 14 and 28 days). The sea sand was partially replaced by river sand at different percentages of $20 \%, 40 \%, 60 \%, 80 \%$ and $100 \%$. The results demonstrated that the compressive strength of this concrete was decreased up to $6.5 \%$ compared to that of conventional concrete. Authors in [10] replaced natural sand at different percentages $10 \%, 20 \%$ and $30 \%$ with foundry sand to manufacture M20 grade concrete. The results concluded that the compressive strength increased significantly as the replacement percentage increased. Meanwhile, the tensile strength was maximum at $20 \%$ replacement.

\section{MATERIALS AND METHODS}

\section{A. Materials}

Ordinary Portland cement CEM I 42.5 N that complies with ASTM C0150-04AE01, branded name as Falcon cement was 
selected for this research work. In this research, the two types of fine aggregates (hill sand and River Indus sand) were used. Material properties like specific gravity, water absorption, fine modulus and color of hill sand and River Indus sand are shown in Tables I and II.

TABLE I. PROPERTIES OF HILL SAND

\begin{tabular}{|c|c|c|}
\hline S.NO & Particulars of test & Test results \\
\hline 1 & Specific gravity & 2.56 \\
\hline 2 & Fineness modulus & $3.01 \%$ \\
\hline 3 & Water absorption & $1.2 \%$ \\
\hline 4 & Color & Light orange \\
\hline
\end{tabular}

TABLE II. PROPERTIES OF INDUS RIVER SAND

\begin{tabular}{|c|c|c|}
\hline S.NO & Particulars of test & Test results \\
\hline 1 & Specific gravity & 2.50 \\
\hline 2 & Fineness modulus & $2.04 \%$ \\
\hline 3 & Water absorption & $3.8 \%$ \\
\hline 4 & Color & Dark grey \\
\hline
\end{tabular}

\section{B. Test Parameters and Mixture Proportions}

Three grades of concrete mixtures (M10, M15 and M20) were studied for this research. Two different kinds of concrete mix were cast, namely conventional concrete using hill sand as fine aggregate and concrete using Indus River sand as fine aggregate. Hill sand was fully replaced with Indus River sand. The cylinders were tested for concrete tensile strength at curing ages of $7,14,21,28$ days. Mixing was carried out using a rotary mixer. The concrete mix workability was checked by standard slump test using standard slump cone and procedure according to ASTM C 143. All the cylinders were extracted from the molds after 24 hours and cured for the required age of testing. The concrete tensile strength was tested using the Universal Testing Machine available in the Civil Engineering Department, MUET Jamshoro, and followed the overall procedure described in ASTM C496/C496M-17.

\section{RESULTS AND DISCUSSION}

\section{A. Slump Test (ASTM C 143)}

For slump test, the ASTM C 143 standard was followed. The workability results of both concretes are shown in Table III. It is seen that the Indus River sand concrete is low workable when compared to the conventional concrete.

TABLE III. WORKABILITY VALUES OF CONCRETE MIXES

\begin{tabular}{|c|c|}
\hline Mixture & Slump Value (mm) \\
\hline Conventional concrete (M15) & 31.75 \\
\hline River sand concrete (M15) & 25.4 \\
\hline Conventional concrete (M20) & 50.8 \\
\hline River sand concrete (M20) & 43.18 \\
\hline Conventional concrete (M25) & 63.5 \\
\hline River sand concrete (M25) & 50.8 \\
\hline
\end{tabular}

\section{B. Tensile Strength}

Tensile strength test was conducted according to the ASTM C496/C496M-17 standard. The Tensile Strength results of both concretes are shown in Table IV and Figures 1-3. The results showed that there was a reduction in the tensile strength of river sand concrete because of the improper material bonding due to the larger amount of clayey particles present in River Indus sand. After 7 days curing, the tensile strength of M15, M20 and M25 river sand concrete decreased by $12.72 \%$, $10.21 \%$ and $5.88 \%$, respectively. After 14 days water curing, the tensile strength of M15, M20 and M25 river sand concrete decreased by $6.87 \%, 3.87 \%$ and $2.79 \%$ respectively. At 21 days water curing, the tensile strength of M15, M20 and M25 river sand concrete decreased by $2.06 \%, 2.77 \%$ and $1.63 \%$, respectively. At 28 days water curing, the tensile strength of M15, M20 and M25 river sand concrete decreased by $1.90 \%$, $1.68 \%$ and $1.08 \%$, respectively.

TABLE IV. TENSILE STRENGTH OF M15, M20 AND M25 GRADE CONCRETE.

\begin{tabular}{|c|c|c|c|c|}
\hline Mixture & 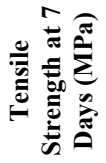 & 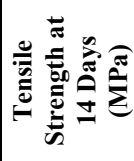 & 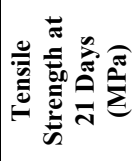 & 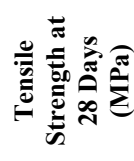 \\
\hline Conventional concrete (M15) & 1.24 & 1.71 & 1.98 & 2.13 \\
\hline River sand concrete (M15) & 1.10 & 1.60 & 1.94 & 2.09 \\
\hline Conventional concrete (M20) & 1.51 & 1.92 & 2.22 & 2.41 \\
\hline River sand concrete (M20) & 1.37 & 1.85 & 2.16 & 2.37 \\
\hline Conventional concrete (M25) & 1.80 & 2.21 & 2.48 & 2.80 \\
\hline River sand concrete (M25) & 1.70 & 2.15 & 2.44 & 2.77 \\
\hline
\end{tabular}

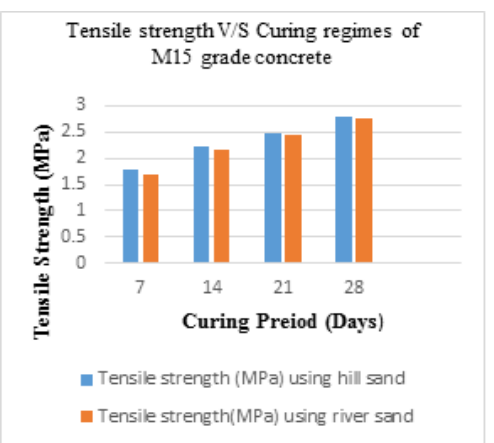

Fig. 1. Tensile strength vs curing regimes of M15 grade concrete

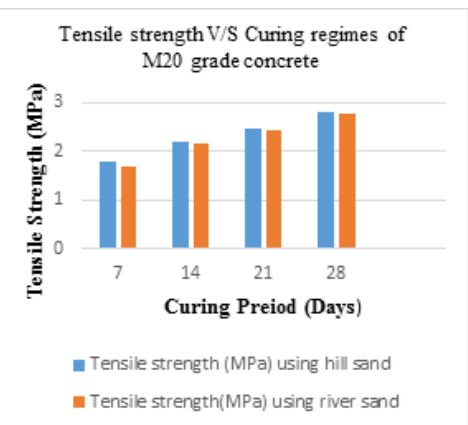

Fig. 2. Tensile strength vs curing regimes of M20 grade concrete 


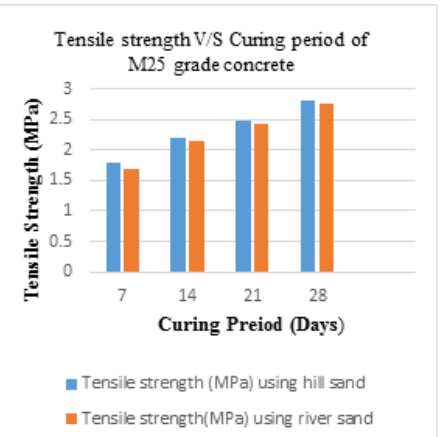

Fig. 3. Tensile strength vs curing regimes of M25 grade concrete

\section{CONCLUSION}

Concrete becomes less workable when Indus River sand is utilized as fine aggregate. For better results of workability, certain admixtures will be required. The results showed the tensile strength of Indus River sand concrete 1\% to 2\% lower than the tensile strength of conventional concrete. Hence, it is concluded that M25 grade concrete gave better results for concrete with Indus River sand as fine aggregate.

\section{REFERENCES}

[1] E. Aprianti S., "A huge number of artificial waste material can be supplementary cementitious material (SCM) for concrete production - a review part II", Journal of Cleaner Production, Vol. 142, No. 4, pp. 4178-4194, 2017

[2] Z. Li, Advanced Concrete Technology, John Wiley and Sons Inc., 2011

[3] A. M. Neville, Properties of concrete, Prentice Hall, 2011

[4] J. P. McLaughlin, K. B. Woods, R. C. Mielenz, N. C. Rockwood, "Distribution, production, and engineering characteristics of aggregates, section 16", in: Highway Engineering Handbook, McGraw-Hill, 1960

[5] C. S. Poon, Z. H. Shui, L. Lam, H. Fok, S. C. Kou, "Influence of Moisture States of Natural and Recycled Aggregates on the Slump and Compressive Strength of Concrete", Cement and Concrete Research, Vol. 34, No. 1, pp. 31-36, 2004

[6] A. Omoregie, O. E. Alutu, "The Influence of Fine Aggregate Combinations on Particle Size Distribution, Grading Parameter, and Compressive Strength of Sandcrete Blocks", Canadian Journal of Civil Engineering, Vol. 33, No. 10, pp. 1271-1278, 2006

[7] A. D. Raval, A. Pamnani, A. I. Kachwala, "Foundry sand: utilization as a partial replacement of fine aggregate for establishing sustainable concrete", International Journal of Engineering Sciences \& Research Technology, Vol. 4, No. 1, pp. 308-311, 2015

[8] D. R, Bhimani, J. Pitroda, J. J. Bhavsar, "Used foundry sand: opportunities for development of ecofriendly low cost concrete", International Journal of Advanced Engineering Technology, Vol. 4, No. 1, pp. 63-66, 2013

[9] D. Chaurasiya, K. Koli, S. Chaudhari, V. More, P. C. Satpute, "Utilization of foundry sand: An Art to replace fine sand with Foundry Sand", International Journal on Theoretical and Applied Research in Mechanical Engineering, Vol. 5, No. 1, pp. 44-48, 2016

[10] K. P. Salokhe, D. B. Desai, "Application of Foundry sand in manufacture of concrete", Second International Conference on Emerging Trends in Engineering (SICETE), Jaysingpur, India, pp. 43-48, 2015 